УДК 371.35

\title{
НОВА УКРАЇНСЬКА ШКОЛА: ВМІННЯ МОЛОДШИХ ШКОЛЯРІВ В АНГЛІЙСЬКОМУ ДІАЛОГІЧНОМУ МОВЛЕННІ
}

\author{
Кочубей Н. П. \\ na-nat@rambler.ru \\ Глухівський начіональний педагогічний університет \\ імені Олександра Довженка \\ Дата надходження 25.10.2018. Рекомендовано до друку 01.12.2018.
}

\begin{abstract}
Анотація. Стаття присвячена проблемі навчання англійського діалогічного мовлення в контексті впровадження нової української школи у систему початкової шкільної освіти. Стаття грунтується на результатах аналізу наукової літератури з проблеми і чинних навчальних програм та державного стандарту. Проведений аналіз дав можливість виокремити необхідні уміння молодших школярів у англійському діалогічному мовленні, які корелюють 3 рівнем A1.1.1 елементарної іншомовної комунікативної компетентності у говорінні та базуються на вимогах чинних нормативних документів в рамках впровадження нової української школи.

Ключові слова: початкова школа, англійське діалогічне мовлення, уміння молодших школярів, нова українська школа.
\end{abstract}

Кочубей Н. П. Глуховский национальный педагогический университет имени Александра Довженко Новая украинская школа: умения младших школьников в английской диалогической речи Аннотация. Статья посвящена проблеме обучения иноязычной диалогической речи в контексте внедрения новой украинской школы в систему начального школьного образования. Статья основана на результатах анализа научной литературы по данному вопросу и действующих программ обучения, а также государственного стандарта. Проведенный анализ позволил выделить необходимые умения младших школьников в английской диалогической речи, которые коррелируют с уровнем A1.1.1 элементарной иноязычной коммуникативной компетентности в говорении и основаны на требованиях нормативных документов в рамках внедрения новой украинской школы.

Ключевые слова: начальная школа, английская диалогическая речь, умения младших школьников, новая украинская школа.

Kochubey N. Oleksandr Dovzhenko Hlukhiv national pedagogical university

New school in Ukraine: primary school pupils' English dialogical speech skills

Abstract. Introduction. The article deals with the question of teaching foreign dialogical speech to the primary school pupils in the context of a new school introduction into the primary school education in Ukraine. Due to the modern globalization trends in education, introduction of the new State educational standard and the launch of a new school in Ukraine, the diverse aspects of learning foreign languages in primary school become a scientific researches' priority. Teaching foreign language in primary school should provide a basis for further learning, stimulate the development of pupil's language skills and mental functions. The Ministry of Education and Science of Ukraine states that much attention should be paid to spoken receptive and productive activities, language communication, as well as to the pupils' communication encouragement. The Purpose is to determine the basic skills of primary school pupils in English dialogical speech taking into account the current trends in teaching and primary school pupils' speech psychological characteristics. Methods. The article is based on the results of the scientific pedagogical, physiological, methodological literature analysis on the problem and the current curricula and the state standard. Results. The analysis made it possible to distinguish the necessary skills of primary school pupils in English dialogical speech. The skills correlate with A1.1.1 level of elementary foreign language communicative competence in speaking and are based on the requirements of the current normative documents within the framework of the new school implementation. Conclusion. To sum up, it was found that primary school pupils have to obtain certain skills in English dialogical speech. Within the educational speech context children have to put and answer simple questions of different types, produce both initiative and 
reactive replicas by simulating certain speech samples, make up mini-dialogues and select the necessary lexical units and speech samples, conduct elementary dialogues, make up questions, make offers, report on, clarify, deny, evaluate something using certain speech samples.

Key words: primary school, English dialogical speech, primary pupils' skills, new school.

Постановка проблеми. Глобалізація освітнього простору, оновлення навчально-методичного забезпечення початкової освіти в контексті нового Державного стандарту початкової загальної середньої освіти, започаткування нової української школи роблять приорітетним дослідження різнопланових аспектів навчання іноземної мови в початковій школі, яке має забезпечити підгрунтя для подальшого ії вивчення й стимулювати розвиток загальномовленнєвих умінь і психічних функцій молодшого школяра. В Методичних рекомендаціях щодо організації процесу навчання іноземних мов у 1-х класах експериментальних загальноосвітніх навчальних закладів МОН України зазначено, що велику увагу слід приділяти усним рецептивним і продуктивним видам діяльності, мовленнєвій комунікації та заохочувати учнів до спілкування (Міністерство освіти і науки України, 2017).

Саме в навчанні спілкування розвивається пізнавальна сфера учнів, формується їхній внутрішній світ, свідомість і здатність бути соціально мобільними в сучасному суспільстві. Особливе значення у навчанні молодших школярів спілкування іноземною мовою має діалог, в якому виникають міжособові відносини, прагнення до спілкування й соціалізації, активізується пізнавальна сфера учнів. Безпосередня участь у діалозі реалізується через діалогічне мовлення, оволодіння яким є умовою повноцінного мовленнєвого розвитку учнів початкової школи.

I. Д. Салістра зазначає, що навчання діалогічного мовлення передбачає формування вміння висловлювати власні думки іноземною мовою. з одного боку, з другого - навчання розуміння мовлення співрозмовника (Салистра, 1958, с. 247). 3 огляду на таке твердження акцентується вагомість діалогічного мовлення, оскільки в ньому поєднуються вираження власних думок і сприйняття мовлення співрозмовника. Проблема навчання діалогічного мовлення досі залишається однією з актуальних проблем методики навчання іноземних мов, що пояснюється специфічністю природи діалогічного мовлення, наявністю багатьох підходів до його вивчення тощо.

Аналіз останніх досліджень і публікацій. Особливості структури, змісту, функції зовнішнього й внутрішнього діалогів у спілкуванні розглянуто М. М. Бахтіним, В. С. Біблером, А. У. Харашем. Вивченню природи діалогу мови й мислення присвячено дослідження Л. С. Виготського, О. О. Леонтьєва, Ю. М. Лотмана, Л. П. Якубинського. Ю. М. Лотман і В. М. М'ясищев розробили універсальні системи комунікації особистої й рольової діалогічної взаємодії та акцентували, що в ході діалогу здійснюються саморозвиток, упевненість і самореалізація його учасників.

Проблемі діалогічної взаємодії вчителя й учня присвячено праці О. О. Бодальова, який зазначає, що діалогічна взаємодія не обмежується лише зв'язком між ними, а уможливлюється за наявності психологічної готовності учня до тих змін, які хотів би внаслідок мати вчитель. Особливої значущості це набуває для навчання молодших школярів, у яких ще відсутній достатній мовний досвід, оскільки в початковій школі починається оволодіння іншомовним мовленнями і мовним матеріалом.

Можливості діалогу як форми спілкування й засобу взаємовпливу також розкриваються в працях О. О. Леонтьєва, І. А. Зязюна, А. У. Хараша. Проблемою усного мовлення, зокрема діалогічного, займалися зарубіжні (Виноградов В. В., Винокур Т. Г., Земська О. А., Щерба Л. В., Якубинський Л. П.) і вітчизняні (Дудик П. С., Палихата Е. Я.) науковці. С. С. Беркнер, В. Д. Дєвкін, Ю. І. Пассов, С. М. Розенбаум, В. Л. Скалкін, Н. К. Скляренко, Ю. М. Скребнєв,

Є. П. Шубін досліджували формування іншомовного діалогічного спілкування.

Психологічні аспекти діалогічної взаємодії обгрунтовано в дослідженнях О. О. Бодалєва і Л. С. Виготського. Можливості діалогу як форми спілкування й засобу взаємовпливу розкрито 
в працях I. А. Зязюна, О. О. Леонтьєва, А. У. Хараша. Комунікативні й інтелектуальні аспекти діалогу акцентовано в роботах В. С. Біблера, С. Л. Братченко, О. М. Матюшкіна, Л. А. Петровської, А. С. Співаковської. Сучасна методика навчання учнів іншомовного мовлення грунтується на теорії мовленнєвої діяльності, основні положення якої розроблено Л. С. Виготським, М. І. Жинкіним, О. О. Леонтьєвим, О. Р. Лурією.

Ю. І. Пассов сформулював принципи і створив модель комунікативного навчання мовлення. О. С. Горшенєва, В. В. Калюжна, І. В. Михалєва досліджували розвиток англійського усного мовлення. В. Л. Скалкін виділив методичні засади навчання англійського діалогічного мовлення й запропоновував відповідну систему вправ і форм роботи для формування й розвитку навичок і вмінь діалогічного мовлення. Н. Д. Гальскова й Н. І. Гез надали психологічну характеристику говорінню, визначили мету навчання, запропонували систему вправ й засади контролю вмінь говоріння. І. М. Верещагіна, Р. П. Мильруд, 3. М. Нікітенко, О. О. Паршикова, Г. В. Рогова, М. Ф. Стронін займались питанням навчання діалогічного мовлення у загальноосвітній школі.

Хоча проблема навчання учнів загальноосвітньої школи іншомовного діалогічного мовлення посідає вагоме місце в наукових дослідженнях, іiї не можна вважати повністю вирішеною в контексті сучасних нововведень у шкільній освіті. Недостатньо розробленим і важливим залишається питання навчання англійського усного діалогічного мовлення молодших школярів.

Мета статті - визначити основні вміння молодших школярів в англійському діалогічному мовленні з урахуванням сучасних тенденцій навчання, а також психологічних особливостей учнів початкової школи.

Основні результати дослідження. 3 розширенням сфери використання парної й групової роботи на уроках у початковій школі дедалі частіше використовується діалогічне мовлення (Гудзик, 2007, с. 213). В. Л. Скалкін визначає діалогічне мовлення як об’єднану ситуацією, темою і комунікативними мотивами сукупність усних висловлювань, послідовно здійснених двома або більше співрозмовниками в безпосередньому акті спілкування (Скалкин, 1989, с. 6).

3 психологічної точки зору діалогічне мовлення завжди звернене, вмотивоване й емоційно забарвлене (Ніколаєва та ін., 1999, сс. 147-148). Реалізуючись у рамках діалогічного спілкування як чергування невеликих висловлювань, діалогічне мовлення межує, з одного боку, з початком (закінченням) комунікативного акту, а 3 другого боку - 3 монологічними вставками, з якими з'єднується за допомогою початкових (кінцевих) речень, що мають діалогічну зв'язаність. Діалогічне мовлення варто розглядати як комунікативний акт, де має місце зміна ролей, коли ініціатива в спілкуванні переходить від одного співрозмовника до іншого. Однак у фізичному плані комуніканти не обмінюються висловлюваннями, а зіставляють ці висловлювання, вибудовуючи їх у послідовно-часовий ряд (Скалкин, 1989, с. 6).

О. І. Вишневський $(1989$, с. 143$)$ зазначає, що найпоширенішою на уроці іноземної мови в початковій школі структурною схемою діалогу є сполучення двох реплік: запитання й відповіді. Проте така діалогічна єдність, за твердженням ученого, не тільки не вичерпує різноманітні форми побудови діалогу, а й не $є$ головною, оскільки структура природного повсякденного діалогу різноманітна і містить широку палітру логічних зв'язків між парами реплік.

На уроці з іноземної мови вчитель прагне, щоб мовлення учнів наближалось до природного, що уможливлюється за умови мовленнєвої ситуації як під час реального спілкування, так і за допомогою завдань. Залежно від цього мовленнєві ситуації класифікують на природні й навчальні. Природні мовленнєві ситуації пов'язані з організацією навчального процесу і мають природний мовленнєвий стимул. Такі ситуації не забезпечують активізації навчального матеріалу. Успішне поєднання спілкування іноземною мовою і засвоєння мовних засобів навчального циклу уможливлюють навчальні мовленнєві ситуації (Панова, Андрійко, Тезікова, 2010, с. 146). Навчальна мовленнєва ситуація розглядається як сукупність життєвих умов, що спонукають до висловлювання думок і використання при цьому мовного матеріалу (Семенчик, 2004, с. 143). 
У Методичних рекомендаціях щодо організації процесу навчання іноземних мов у 1-х класах експериментальних загальноосвітніх навчальних закладів зазначено, що початковий ступінь навчання іноземної мови надзвичайно важливий, оскільки в цей період закладаються психолінгвістичні основи іншомовної комунікативної компетентності, необхідні й достатні для подальшого ії розвитку й удосконалення. Відбувається становлення засад для формування вмінь сприймати на слух, говорити, читати й писати іноземною мовою Відтак, постає питання виділення необхідних мовленнєвих умінь для навчання англійського діалогічного мовлення в межах визначених програмою результатів навчально-пізнавальної діяльності учнів, що узгоджуються із Загальноєвропейськими Рекомендаціями з мовної освіти.

Для початкового ступеня навчання Г. В. Рогова й І. М. Верещагіна виділяють основні мовленнєві вміння, які формуються в учнів у процесі навчання іншомовного діалогічного мовлення, 3-поміж яких стимулювання співрозмовника до висловлювання, реагування на мовленнєвий стимул, розгортання репліки-відповіді (Рогова и Верещагина, 1988, сс. 140-141).

3 метою конкретизації вимог до рівня розвитку вмінь у діалогічному мовленні наведемо їхню порівняльну характеристику (табл. 1).

Вимоги до рівня розвитку вмінь

\section{в англійському діалогічному мовленні молодших школярів}

\begin{tabular}{|c|c|}
\hline Документ & Вимоги \\
\hline $\begin{array}{l}\text { Державні вимоги до рівня } \\
\text { загальноосвітньої підготовки } \\
\text { учнів початкової школи } \\
\text { в освітній галузі “Мови } \\
\text { і література. Іноземна мова" }\end{array}$ & $\begin{array}{l}\text { - використовувати відомий лексичний і граматичний матеріал } \\
\text { в усному спілкуванні; } \\
\text { - розуміти на слух мовлення вчителя, однокласників, основний } \\
\text { зміст текстів з опорою на наочність і мовну здогадку; } \\
\text { - брати участь у діалогічному спілкуванні: вести етикетний } \\
\text { діалог й елементарний діалог-розпитування у межах ситуацій } \\
\text { повсякденного спілкування (Кабінет Міністрів України, 2011). }\end{array}$ \\
\hline $\begin{array}{l}\text { Навчальні програми з } \\
\text { іноземних мов для } \\
\text { загальноосвітніх навчальних } \\
\text { закладів і спеціалізованих } \\
\text { шкіл із поглибленим } \\
\text { вивченням іноземних мов } \\
1-4 \text { класи } \\
\end{array}$ & $\begin{array}{l}\text { - ставити загальні й нескладні спеціальні питання; } \\
\text { - відповідати на них згідно з мовним матеріалом і ситуацією } \\
\text { спілкування; } \\
\text { - реагувати на прості, в дещо уповільненому темпі, репліки } \\
\text { вчителя й однокласників; } \\
\text { - обмінюватися репліками на рівні міні-діалогу (висловлювання } \\
\text { кожного учня не менше 3-х реплік) (“Навчальні програми...”). }\end{array}$ \\
\hline \multirow[t]{2}{*}{$\begin{array}{l}\text { Загальноєвропейські } \\
\text { Рекомендації } 3 \text { мовної освіти: } \\
\text { вивчення, викладання, } \\
\text { оцінювання }\end{array}$} & $\begin{array}{l}\text { Рівень володіння іноземною мовою на кінець четвертого } \\
\text { класу має відповідати рівню А1, який вважається найнижчим } \\
\text { рівнем використання мови, коли той, хто навчається, може } \\
\text { спілкуватись простими засобами, ставити нескладні запитання } \\
\text { й відповідати на них, ініціювати й підтримувати розмову } \\
\text { простими репліками (Ніколаєва, 2003, с. } 33 \text { ). }\end{array}$ \\
\hline & $\begin{array}{l}\text { Для рівня володіння діалогічним мовленням А1 виділено } \\
\text { такі дескриптори: } \\
\text { - ініціювати й відповідати на прості твердження щодо } \\
\text { нагальних потреб або дуже знайомих тем; } \\
\text { - на рівні бесіди - відрекомендувати себе, використовувати } \\
\text { елементарні засоби привітання й підтримання бесіди, запитати, } \\
\text { як справи, відреагувати на новини; } \\
\text { запитувати й відповідати на запитання про себе й інших } \\
\text { людей, вказувати на час, спілкуватися простими висловлюваннями } \\
\text { на знайомі теми (Ніколаєва, 2003, с. 33). }\end{array}$ \\
\hline
\end{tabular}


Продовження табл. 1

На основі зазначеного виділено вимоги до рівня
загальноосвітньої підготовки учнів в англійському діалогічному
мовленні: спілкуватись із співрозмовником у простих типових
ситуаціях; робити запит нової інформації, використовуючи
для цього запитання різних типів; висловлювати радість,
захоплення, подив, згоду, незгоду, сумнів у зв’язку з почутим
від співрозмовника; ставити запитання співрозмовникові
з метою з'ясування або уточнення певної інформації, що
зустрічається у процесі спілкування, і відповідати на подібні
запитання; обмінюватися репліками із співрозмовником;
перезапитати співрозмовника з метою уточнення змісту
в разі нерозуміння його (Ніколаєва, 2003, сс. 74-82).

Отже, основними вміннями учнів початкової школи в англійському діалогічному мовленні $€$ ставити й відповідати на нескладні за змістом запитання різного типу; будувати як ініціативні, так і реактивні репліки; створювати нескладні міні-діалоги з різних тем; вести елементарний діалог відповідно до прочитаного, прослуханого або побаченого в межах мовленнєвих ситуацій, визначених програмою, самостійно використовуючи програмний мовний матеріал для реалізації комунікативних завдань. 3-поміж найтиповіших виділяють уміння розпитати, запропонувати, повідомити, уточнити, заперечити, оцінити тощо.

Передумовами навчання молодших школярів є довільність їхніх пізнавальних процесів, уміння перетворювати матеріалізовані дії в мовленнєві, відповідати на запитання своїми словами й ставити запитання. Формування навчальної діяльності охоплює три етапи: формування вмінь розуміння навчального завдання й виконання дій у типовій ситуації за зразком; оволодіння загальним способом дій; стабільне засвоєння закономірностей мови і використання їх для формулювання висловлювань. На першому етапі учні шести-восьми років засвоюють первинні форми вміння вчитись. Найбільш значущими 3-поміж них є вміння розуміти навчальне завдання й виконувати його за зразком, а також, застосовуючи вже засвоєний спосіб виконання розумових дій (Нгуен Ке Хао, 1986, с. 13). Ми визначаємо первинні навчальні вміння молодших школярів в оволодінні англійським діалогічним мовленням слідом за О. О. Паршиковою (2010, с. 123), яка, враховуючи зазначені етапи формування навчальної діяльності молодших школярів, визначає первинні навчальні вміння молодших школярів в оволодінні іншомовним спілкуванням. Отже, первинні навчальні вміння молодших школярів в оволодінні англійським діалогічним мовленням містять уміння розуміти комунікативні завдання в діалогах і вирішувати їх за рахунок упізнавання, розуміння й репродукції засвоєних мовленнєвих зразків, їх вибору й застосування без змін і з незначними змінами за рахунок операцій підстановки, заміщення, скорочення, розширення реплік діалогу.

Ураховуючи те, що рівень володіння іншомовним спілкуванням у початковій школі визначено як A1 на кінець 4-го класу, конкретизуємо проміжні рівні елементарної іншомовної комунікативної компетентності й виділимо рівні навчання учнів 1-го класу англійського діалогічного мовлення. Слідом за О. О. Паршиковою (2010, с. 226), рівень володіння мовою А1 поділяємо на А1.1, якого мають досягти учні після першого семестру другого року вивчення іноземної мови, й рівень А1.2 - на кінець навчання в початковій школі. 3 огляду на особливості спілкування учнів початкової школи, виділено типи елементарного іншомовного спілкування, які корелюють 3 підрівнями А1.1.1 (квазікомунікація) і А1.1.2 (протокомунікація) (Паршикова, 2010, с. 226). Першому року вивчення іноземної мови відповідає підрівень А1.1.1. Завдання формування в учнів початкової загальноосвітньої школи мовленнєвого складника іншомовної комунікативної 
Кочубей Н. П. Нова українська школа: вміння молодших школярів в англійському діалогічному мовленні

компетентності в говорінні полягають у репродукуванні висловлювання на основі вибору, артикуляційної й інтонаційної актуалізації засвоєних лексичних одиниць і мовленнєвих зразків адекватно ситуації й комунікативному завданню без змін на рівні А1.1.1 (Паршикова, 2010, с. 178). Мовленнєвий складник елементарної іншомовної комунікативної компетентності у говорінні на підрівні А1.1.1 передбачає вміння виконувати комунікативне завдання за рахунок точної імітації (безпосередньої й відстроченої) окремих лексичних одиниць і мовленнєвих зразків; уміння вибирати відповідно до комунікативного завдання засвоєні лексичні одиниці й мовленнєві зразки та коректно з точки зору артикуляції, ритму й інтонації відтворювати їх у типовій ситуації спілкування (Паршикова, 2010, с. 215).

Отже, конкретизуючи вимоги нормативних документів і вимоги до підрівня А1.1.1 володіння іноземною мовою, ми виділяємо основні вміння молодших школярів в англійському діалогічному мовленні:

- ставити й відповідати на нескладні за змістом запитання різного типу за рахунок імітації певних мовленнєвих зразків без змін або зі зміненими лексичними одиницями;

- будувати ініціативні й реактивні репліки за рахунок імітації певних мовленнєвих зразків без змін або зі зміненими лексичними одиницями;

- створювати міні-діалоги за рахунок точної імітації (безпосередньої й відстроченої) окремих лексичних одиниць і мовленнєвих зразків і відбирати для цього необхідні лексичні одиниці й мовленнєві зразки;

- вести елементарний діалог відповідно до прочитаного, прослуханого або побаченого в межах мовленнєвих ситуацій, визначених програмою, самостійно добираючи лексичні одиниці й мовленнєві зразки;

- розпитати, запропонувати, повідомити, уточнити, заперечити, оцінити за рахунок імітації певних мовленнєвих зразків без змін або зі зміненими лексичними одиницями.

Висновки і перспективи подальших розвідок. Таким чином, на основі аналізу наукової літератури і новітніх вимог до навчання іноземних мов у початковій школі ми виділили основні вміння молодших школярів в англійському діалогічному мовленні, якими вони мають оволодіти по закінченні 1-го класу: ставити й відповідати на нескладні за змістом запитання різного типу за рахунок імітації певних мовленнєвих зразків; будувати ініціативні й реактивні репліки за рахунок імітації певних мовленнєвих зразків; створювати міні-діалоги й відбирати для цього необхідні лексичні одиниці й мовленнєві зразки; вести елементарний діалог відповідно до прочитаного, прослуханого або побаченого у межах мовленнєвих ситуацій; розпитати, запропонувати, повідомити, уточнити, заперечити, оцінити за рахунок імітації певних мовленнєвих зразків. Ці вміння мають бути реалізовані в межах навчальних мовленнєвих ситуацій на уроках англійської мови. Зазначені вміння можуть бути прийняті до уваги вчителями початкової школи під час планування процесу навчання, авторами підручників і посібників для навчання молодших школярів англійської мови, студентами під час проходження педагогічної практики в початковій школі.

\section{ЛІТЕРАТУРА}

Вишневський, О. І. (1989). Діяльність учнів на урочі іноземної мови. Київ: Радянська школа. Гудзик, И. Ф. (2007). Компетентностно ориентированное обучение русскому языку в начальных классах (в школах с украинским языком обучения). Чернівці: Видавничий дім “Букрек”.

Кабінет Міністрів України. (2011). Державний стандарт початкової загальної освіти [Чинний від 20 квітня 2011 р. № 462]. Взято з: Режим доступу : http://osvita.ua/legislation/ Ser_osv/17911/.

Міністерство освіти і науки України. (2017). Лист № 91/9-503 від 15.09.2017: Щодо методичних рекомендацій з іноземних мов для експериментальних загальноосвітніх навчальних закладів. Взято 3: https://ru.osvita.ua/legislation/other/57412/. 
Ніколаєва, С. Ю. (Наук. ред.). (2003). Загальноєвропейські Рекомендаиї̈ з мовної освіти : вивчення, викладання, оцінювання. Київ: Ленвіт.

Ніколаєва, С. Ю., Бігич, О. Б., Бражник, Н. О., Гапонова, С. В., Онищенко, К.І. (1999). Методика навчання іноземних мов у середніх навчальних закладах. Київ: Ленвіт.

Панова Л. С., Андрійко І. Ф., Тезікова С. В. (2010). Методика навчання іноземних мов у загальноосвітніх навчальних закладах. Київ: ВЦ “Академія”.

Навчальні програми з іноземних мов для загальноосвітніх навчальних закладів і спеціалізованих шкіл із поглибленим вивченням іноземних мов 1-4 класи. Взято 3: https:/mon.gov.ua/storage/ app/media/zagalna\%20serednya/programy-1-4-klas/inozemna-mova-poyasnyuvalna-znz-sznz-14-klas-belyaeva-xarchenko-finalna-zv.pdf.

Нгуен Ке Хао. (1986). Психологические основы формирования учебной деятельности младиих школьников (Автореферат докторсской диссертации). Москва.

Паршикова, О. О. (2010). Теоретичні основи навчання іноземної мови учнів початкової загальноосвітньої школи (Докторська дисертація). Київський національний лінгвістичний університет, Київ, Україна.

Рогова, Г. В. и Верещагина, И. Н. (1988). Методика обучения английскому языку на начальном этапе в средней школе. Москва: Просвещение.

Салистра, И. Д. (1958). Методика обучения немецкому языку в средней. Москва: Учпедгиз.

Семенчик, Ю. О. (2004). Іноземна мова для реального життя (моделювання комунікативних ситуацій для формування вмінь іноземномовного ділового спілкування). Іноземні мови в навчальних закладах, 2, 143-152.

Скалки, В. Л. (1989). Обучение диалогической речи (на материале английского языка). Київ: Радянська школа.

\section{REFERENCES}

Vyshnevs'kyj, O. I. (1989). Diial'nist' uchniv na urotsi inozemnoi movy. Kyiv: Radians'ka shkola.

Gudzyk, Y. F. (2007). Kompetentnostno oryentyrovannoe obuchenye russkomu iazyku v nachal'nykh klassakh (v shkolakh s ukraynskym iazykom obuchenyia). Chernivtsi: Vydavnychyj dim "Bukrek".

Kabinet Ministriv Ukrainy. (2011). Derzhavnyj standart pochatkovoi zahal'noi osvity [Chynnyj vid 20 kvitnia 2011 r. № 462]. Vziato z: Rezhym dostupu : http://osvita.ua/legislation/Ser_osv/17911/.

Ministerstvo osvity i nauky Ukrainy. (2017). Lyst № 91/9-503 vid 15.09.2017: Schodo metodychnykh rekomendatsij z inozemnykh mov dlia eksperymental'nykh zahal'noosvitnikh navchal'nykh zakladiv. Vziato z: https://ru.osvita.ua/legislation/other/57412/.

Nikolaieva, S. Yu. (Nauk. red.). (2003). Zahal'noievropejs'ki Rekomendatsii z movnoi osvity : vyvchennia, vykladannia, otsiniuvannia. Kyiv: Lenvit.

Nikolaieva, S. Yu., Bihych, O. B., Brazhnyk, N. O., Haponova, S. V., Onyschenko, K.I. (1999). Metodyka navchannia inozemnykh mov u serednikh navchal'nykh zakladakh. Kyiv: Lenvit.

Panova L. S., Andrijko I. F., Tezikova S. V. (2010). Metodyka navchannia inozemnykh mov u zahal'noosvitnikh navchal'nykh zakladakh. Kyiv: VTs "Akademiia".

Navchal'ni prohramy z inozemnykh mov dlia zahal'noosvitnikh navchal'nykh zakladiv i spetsializovanykh shkil iz pohlyblenym vyvchenniam inozemnykh mov 1-4 klasy. Vziato z: https://mon.gov.ua/storage/ app/media/zagalna\%20serednya/programy-1-4-klas/inozemna-mova-poyasnyuvalna-znz-sznz1-4-klas-belyaeva-xarchenko-finalna-zv.pdf.

Nhuen Ke Khao. (1986). Psykholohycheskye osnovy formyrovanyia uchebnoj deiatel'nosty mladshykh shkol'nykov (Avtoreferat doktorsskoj dyssertatsyy). Moskva.

Parshykova, O. O. (2010). Teoretychni osnovy navchannia inozemnoi movy uchniv pochatkovoi zahal'noosvitn'oi shkoly (Doktors'ka dysertatsiia). Kyivs'kyj natsional'nyj linhvistychnyj universytet, Kyiv, Ukraina. 
Rohova, H. V. y Vereschahyna, Y. N. (1988). Metodyka obuchenyia anhlyjskomu iazyku na nachal'nom etape v srednej shkole. Moskva: Prosveschenye.

Salystra, Y. D. (1958). Metodyka obuchenyia nemetskomu iazyku v srednej. Moskva: Uchpedhyz. Semenchyk, Yu. O. (2004). Inozemna mova dlia real'noho zhyttia (modeliuvannia komunikatyvnykh sytuatsij dlia formuvannia vmin' inozemnomovnoho dilovoho spilkuvannia). Inozemni movy v navchal'nykh zakladakh, 2, 143-152.

Skalky, V. L. (1989). Obuchenye dyalohycheskoj rechy (na materyale anhlyjskoho iazyka). Kyiv: Radians'ka shkola. 